\title{
Wie pandektistisch war die Pandektistik?
}

\author{
Symposium aus Anlass des 80. Geburtstags von Klaus Luig am 11. September 2015 \\ Hrsg. v. Hans-Peter Haferkamp u. Tilman Repgen
}

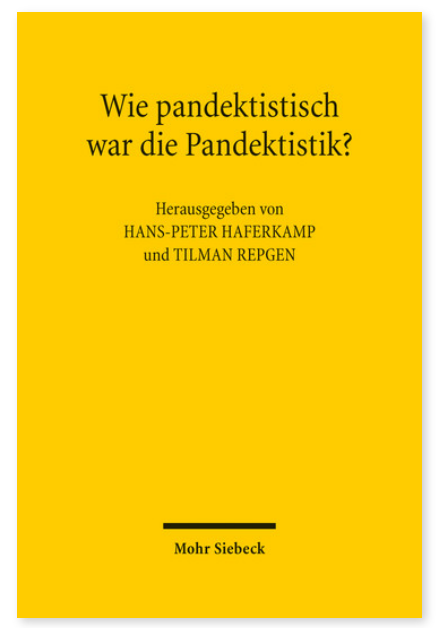

2017. VIII, 308 Seiten.

ISBN 978-3-16-155459-9 DOI 10.1628/978-3-16-155459-9 eBook PDF 114,00€ ISBN 978-3-16-155070-6 Leinen $114,00 €$
Der schillernde Begriff »Pandektistik« wird meist in pejorativem Sinn als Beschreibung für eine Rechtswissenschaft verwendet, von der es sich abzugrenzen gilt. Dabei spielt Jherings 1884 vehement einsetzende Kritik an einer nur-logischen, haarspalterischen, weltfremden »Begriffsjurisprudenz« der Pandektistik eine erhebliche Rolle. Wir wissen inzwischen, dass diese Kritik stark überspitzt, teilweise unrichtig war. Die Tagung brachte die beiden bis heute meist getrennt zu diesen Zusammenhängen forschenden Rechtshistorikergruppen, die eher dogmatisch und dogmengeschichtlich auf die Pandektenwissenschaft blickenden »Romanisten« und die eher wissenschaftsgeschichtlich dem gleichen Gegenstand zugewandten »Germanisten« erstmals in einer Tagung gezielt in ein Gespräch über diesen Befund. Die entstandenen Beiträge verstehen sich als Bausteine zu einer neuen Sichtweise auf die Pandektenwissenschaft des 19. Jahrhunderts.

\section{Inhaltsübersicht}

Hans-Peter Haferkamp/Tilman Repgen: "Wie pandektistisch ist die Pandektistik«? - Einleitung - Franz-Stefan Meissel: Joseph Unger und das Römische Recht - Zu Stil und Methoden der österreichischen »Pandektistik« - Martin Avenarius: Rechtswissenschaft als »Dogma«. Die Ablösung der Dogmatik vom positiven Recht und die Weiterentwicklung des Rechtsdenkens in Russland - Marju Luts-Sootak: Zu der Universalität der Pandektenwissenschaft - am Beispiel der baltischen Privatrechtswissenschaft nach der Kodifikation von 1864 geprüft - Riccardo Cardilli: Das römische Recht der Pandektistik und das römische Recht der Römer - Ulrich Falk: Haftung des Konkursverwalters in der Rechtsprechung des Reichsgerichts vor 1900: »Höchste Ungerechtigkeit und Willkühr«? - Nils Jansen: Naturrechtsfäden im Gewebe pandektistischer Theoriebildung: drei Beispiele aus dem Recht der Schuldverhältnisse - Boudewijn Sirks: War Mühlenbruch ein Pandektist? - Joachim Rückert: Pandektistische Leistungsstörungen? - Thomas Rüfner: Pandektistik und Prozessrecht - Martin Schermaier: »... nicht mit Willkühr ersonnen, sondern seit Jahrhunderten bereitet«: Die Auslegung römischer Quellen bei Savigny - Jan Schröder: Zur Aequitas/Billigkeit in der Rechtstheorie des 19. Jahrhunderts

Hans-Peter Haferkamp ist Direktor des Instituts für Neuere Privatrechtsgeschichte, Deutsche und Rheinische Rechtsgeschichte, Universität zu Köln.

Tilman Repgen ist Professor für Deutsche Rechtsgeschichte, Neuere Privatrechtsgeschichte und Bürgerliches Recht an der Universität Hamburg.

Klaus Luig war ordentlicher Professor für Bürgerliches Recht, Römisches Recht und Neuere Privatrechtsgeschichte an den Universitäten Passau und Köln sowie Dekan der Rechtswissenschaftlichen Fakultät in Köln.

Jetzt bestellen:

https://mohrsiebeck.com/buch/wie-pandektistisch-war-die-pandektistik-9783161554599?no_cache=1 order@mohrsiebeck.com

Telefon: +49 (0)7071-923-17

Telefax: +49(0)7071-51104 